\title{
Reply to comment(s) on "Emplacement history and evolution of the Deccan Volcanic Province, India, by Kale et al. (2020)" by Sudha Vaddadi
}

\author{
${ }^{1}$ Advanced Center for Water Resources Development and Management (ACWADAM), Kshipra Society, Pune 411058, India; \\ *Corresponding author, E-mail: dr.vivekale@gmail.com \\ ${ }^{2}$ Geological Survey of India (CR), SU: Maharashtra, Alandi Road, Pune 411006, India \\ ${ }^{3}$ Department of Earth Sciences, Indian Institute of Technology (Bombay), Powai, Mumbai 400076; India
}

(Received: July 1, 2020; Revised accepted: July 13, 2020)

https://doi.org/10.18814/epiiugs/2020/020073

We welcome the comments by Dr. Sudha Vaddadi in the spirit of exchange of views and the additional information shared by her. While we endorse her concluding statement that 'good scientific.... possible only when scientists work together... collaboration', she seems to have failed to appreciate that this compilation represents a collaboration between the officers of the GSI and the academia in the first place! We further submit that these collaborative inputs from two of us (MB \& PC) to this paper were reviewed and approved for publication by the GSI. We respond to Dr. Vaddadi as an individual; and not as a retired geologist from the Geological Survey of India (GSI) that she professes as having been improperly represented. The comments by Dr. Vaddadi are an unfortunate and scientifically skewed view of the compilation made in our paper (Kale et al., 2020). Dr. Vaddadi does not appear to understand that a review article of this nature is bound by space limitations and hence can only include a limited set of citations. The universal thumb-rule in all such situations is that the citation of the most recent / relevant publication for a particular point being discussed assumes that all 'citations therein' are implicitly covered and need not be listed again.

We unambiguously and unabashedly acknowledge the monumental work done on the Deccan Volcanic Province (DVP) by the officers and scientists of the GSI as well as the academia. This work spans more than two centuries and not just 'several decades' as Dr. Vaddadi wrongly states in her opening sentence (“... since the 1967 Koyna earthquake"). Unfortunately, more than $90 \%$ of the GSI data still continue to be in unpublished reports or publications that are not easily accessible by the international community. Without taking anything away from the efforts and meticulous documentation of the GSI, citing such observations, data and research that is inaccessible to the researchers serves no purpose. Our repeated citation (collectively mentioned as "GSI, 2001") of the District Resource Map (DRM) data covers and acknowledges this effort very emphatically. As elucidated by Dr. Vaddadi, the DRM and Quadrangle sheets published by the GSI represent a compilation of all such preceding data and therefore (a) by citing this work we implicitly acknowledge all the inputs that have gone into these compilations and (b) the question of 'ignoring' the GSI work does not arise and is an unfounded and void criticism.
We record our objection to the statements on the lithostratigraphy made by Dr. Vaddadi like '... are a few discrepancies' (line 3, para 6 ), '... is incorrect' (line 5, para 6 and line 2, para 8). She appears to have drawn unscientific conclusions which are either based on her own imagination or based on publications that have been superseded by subsequent work. The following points are noted in this context:

1. The title of our Table 1 (Kale et al., 2020) clearly states that "no lateral correlation of lithostratigraphic units is implied..". So where does Dr. Vaddadi draw her conclusion that "equivalence shown in the table is incorrect'? How can something that is neither implied nor suggested nor concluded be wrong??

2. The work of Thorat and Subbarao (1996) cited by Dr. Vaddadi (Gondwana Geological Society Special Publication. v. 2 p. 39-68, p. 6980 ) does not exist in the volume mentioned at all! That particular volume has papers by Yedekar et al. (p. 39-68) and Sengupta and Deshmukh (p. 69-80). Similarly, the citation Sharma et al (1999) mentions volume number 54 of the Gondwana Geological Society Special Publication. The website of the Gondwana Geological Society shows that they have only published 18 special publications. So, where are these citations from?

3. Nonetheless, assuming that there is some work related to the megacrystic horizons published in 1996, we believe that subsequent compilations in the DRM and Quadrangle sheets would have addressed these findings. Both these compilations (GSI, 2001) mention only 4 megacrystic basalts (GPBs). Therefore the entire arguments and comment that 'authors have not updated their data with recent information' (line 16, para 6) is fallacious and illogical.

4. The same applies to her arguments regarding presence of a 'Middle Ratangarh Formation' (in para 6) and the Satpura Group. If the subsequent compilations by the GSI (including the most recent $2^{\text {nd }}$ edition of the Geological Quadrangle Maps compiled between 2013 and 2017) ignore them, it is logical to expect that they were found to be unacceptable by GSI; and we endorse this view. The Lower and Upper Ratangarh formations are valid and the suggestion of an intervening Middle Ratangarh is not tenable. It may be added that the proposal of Nair and Bhusari (2001) of six formations of the Satpura Subgroup (named as 1 to 6) does not adhere to any code of stratigraphic nomen- 
clature. We have therefore not included them in our compilation.

The earliest stratigraphic classification of the DVP into the lower, middle and upper traps (e.g., Pascoe, 1959; Krishnan, 1968) was replaced by the chemostratigraphic framework based on the chemical compositions for the western DVP (Subbarao and Hooper, 1988). The stratigraphic implications and long distance correlations based on chemistry by subsequent workers have been found to be unjustifiable on geochronological and paleomagnetic grounds. The meticulous work of the GSI has been compiled in the zonal stratigraphy that now takes shape (Kale et al., 2019, 2020). Some of the most recent publications (e.g., Eddy et al., 2020; Schoene et al., 2020) too prefer the zonal stratigraphy rather than extrapolation of the western chemical stratigraphy across the province. Work on these lines is continuing. We further reiterate our own conclusion regarding the stratigraphic classification of the DVP that (a) a zonal stratigraphy provides a more robust framework for correlating the lava sequences and (b) the details of this are rather sketchy at this instant and need to be enriched from future studies. This is what the work of the GSI brought out in the first place (GSI, 2001), and exactly what we have expanded further. We have only provided the broad state-of-the-art framework for the stratigraphy. Future work will provide a more robust understanding and reaffirm, modify or replace parts or whole of this stratigraphy.

The impression that we get after reading the extended rambling by Dr. Vaddadi on the lava tubes and flow-by-flow mapping, is that she does not seem to be aware of the recent development in the volcanological architecture and models of flood basalt provinces. Additionally, she has found it convenient to wrongly attribute conclusions that we have not even suggested, such as (para 10, line1) 'relate the lobate flows to typical channel-fed pahoehoe flows'. We wonder where she read this in our paper or what led to this conclusion. We do not in any way suggest any such relation. Our responses on the volcanological aspects discussed by her are as follows:

1. We (Kale et al., 2020) summarised the morphological types (based on duly cited previous work and our own observations) known from the DVP in Fig. 5, since the space limitation did not allow a detailed discussion of each type. It has been demonstrated that most of the morphologies in the DVP can be explained as variations of endogenously emplaced basaltic lava (= pahoehoe-type in the Hawaiian analogy) and represent local conditions and features that developed at the point where the lava cooled (Self et al., 1998; Kesthelyi et al., 1999; Bondre et al., 2000; 2004; Bodas and Sen, 2014; Kale, 2020). A normal consequence of this is that lateral variations of morphological types within a single lava flow field are expected and have been recorded from the DVP (Duraiswami et al., 2008, 2014; Sen, 2017; Chatterjee and Dash, 2017). However, the recommendation presented in our paper is that it may be more appropriate to categorise the piles of lava flows into lobate and sheet types rather than the earlier nomenclature that tended to be confusing. At no point have we linked these two fundamental types with any specific lava type as wrongly alluded by Dr. Vaddadi.

2. The comments by Dr. Vaddadi on the flow-by-flow mapping and correlation of flows displays a disregard for the fact that most of these 'flows' are lobes / sheet lobes form a flow-field. Morphological variations in successive lobes of a flow-field and laterally as well, are an inherent character of continental flood basalts (e.g., Waichel et al., 2012; Oskarsson and Riishuus, 2014; Bernardi et al., 2015; Browne et al., 2017;
Rossetti et al., 2018). The recent publication of the Rajgad GPB (Shandilya et al., 2020) is a perfect example of how one encounters lateral variations in the morphology of lobes within a flow-field. It is therefore necessary to map a flow-field and the variations within it to appreciate the morphological differences and their distribution across the flow-field. Correlations across long distances must take into account all such variations.

3. We request Dr. Vaddadi to spend some time reading the work of Chatterjee and Dash (2017) before making sweeping comments on it. This is an exhaustive work (integrating the earlier compilations in the relevant Geological Quadrangle Sheets and several internal projects of the GSI, such as JALDHARA, etc) on a 1:50,000 scale flow-by-flow mapping across more than $1000 \mathrm{~km}^{2}$, including 60 measured sections and numerous spot checks and supported by petrographic and geochemical studies. The sections from this report used by us are backed up with all that data and are not flimsy 'section measurements' as suggested by Dr. Vadaddi.

4. Lava tubes and channels are an integral component of the spread of basaltic lava in a flood basalt province, but then, so are lobes, tumuli, squeeze-ups, ropy surfaces, vesicle cylinders, inflated crusts, lava tunnels, war-bonnets, entablatures, etc (see Bodas and Sen, 2014; Sheth, 2017). It was not possible for us to review each of these features individually in this paper, given the size limitations. We acknowledge that recognition of lava tubes / channels emerged from the work of GSI as noted by Dr. Vaddadi. Some of them have indeed been elaborately and unambiguously recorded (e.g., Sharma and Vaddadi, 1996; Sen et al., 2012). However, many of these 'tubes / channels' mapped by remote sensing (Misra, 2002) were eventually questioned (e.g., Dole et al., 2002). Moreover, most of the mapped lava tubes and channels appear to be restricted to a specific stratigraphic horizon in the Western DVP. This limited occurrence and debatable widespread presence precludes their specific mention when discussing the evolution of the DVP as a whole.

5. Finally, while commenting on long distance chemical correlations and multiple effusive centres (para 3), Dr. Vaddadi has used the work of Mishra et al. (2005) to justify it. The earliest critique on long distance chemical correlations was by Deshmukh et al. (1996, p. 14, "stratigraphic comparison between widely separated areas are likely to be unrealistic and misleading...") to our knowledge. Similarly, Auden (1949) was the first to propose a polycentric, dyke-fed fissure type eruptive model for the Deccan Traps; while Kale et al (1992) had questioned the monocentric eruptive model based on chemostratigraphy. Many other authors have said so subsequently, but it was not possible to cite all of them either. In any case, we find it curious that Dr. Vaddadi selectively finds only a 2005 citation to criticise our observations. We have not claimed to have made these interpretations for the first time; although we provide data to justify these conclusions.

In conclusion we appreciate the list of citations shared by Dr. Vaddadi in her comments, with a caution that some of them are inaccessible in the public domain or are wrong citations (as pointed out above). The comments are full of innuendos and distasteful misrepresentations that have no valid scientific basis.

We welcome any proactive exchange of ideas and have no hesitation in conceding that what we have compiled is a 'status report', with possible interpretations rather than a definitive conclusion. The multidisciplinary studies in the DVP are work in progress. We completely 
concur that only constructive collaborations and integration of volcanology, petrology, structural analyses, geochemistry, geochronology and paleomagnetic data with a greater granularity will enable a more rapid growth of knowledge on this large igneous province in the days to come.

\section{References}

Auden, J.B., 1949, Dykes in western India - A discussion on their relationship with the Deccan Traps. Transactions of the National Institute of Science, v. 3, pp. 127-157.

Bernardi, M.I., Bertotto, G.W., Jalowitzki, T.L.R., Orihashi, Y. and Ponce, A.D., 2015, Emplacement history and inflation evidence of a long basaltic lava flow located in southern Payenia volcanic province, Argentina. Journal Volcanology and Geothermal Research, v. 293, pp. 46-56.

Bodas, M.S. and Sen, B., 2014, Glimpses of Deccan Volcanism - characteristics and landscapes. Geological Survey of India, Kolkata, 99 p.

Bondre, N.R., Dole, G., Phadnis, V.M., Duraiswami, R.A., and Kale, V.S., 2000, Inflated pahoehoe lavas from the Sangamner area of the western Deccan Volcanic Province. Current Science, v. 78, pp. 1004-1007.

Bondre, N.R., Duraiswami, R.A., and Dole, G., 2004, Morphology and emplacement of flows from the Deccan Volcanic Province, India. Bulletin of Volcanology, v. 66, pp. 29-45.

Browne, B.L., Becerra, R., Campbell, C., Saleen, P. and Wille, F.R., 2017, Quaternary basaltic volcanism in the Golden Trout Volcanic Field, southern Sierra Nevada, California. Journal Volcanology and Geothermal Research, v. 343, pp. 25-44. doi:10.1016/j.volcgeores.2017.05.028

Dole, G., Bondre, N., Duraiswami, R.A. and Kale, V.S. 2002, Discussion : Arterial system of lava tubes and channels within the Deccan volcanics of western India. Journal Geological Society India, v. 60, pp. 597600.

Duraiswami, R.A., Bondre, N.R., and Managave, S., 2008, Morphology of rubbly pāhoehoe (simple) flows from the Deccan Volcanic Province: implications on style of emplacement. Journal Volcanology and Geothermal Research, Journal of Volcanology and Geothermal Research v. 177 , pp. $822-836$.

Duraiswami, R.A., Gadpallu, P., Shaikh, T.N., and Cardin, N., 2014, Pāhoehoe - a' à transitions in the lava flow fields of the western Deccan Traps, India - implications for emplacement dynamics, flood basalt architecture and volcanic stratigraphy. Journal Asian Earth Science, v. 84, pp. 146-166.

Eddy, M.P., Schoene, B., Samperton, K.M., Keller, G., Adatte, T., and Khadri, S.F.R., 2020, U-Pb zirocon age constraints on the earliest eruptions of Deccan Large Igneous Province, Malwa Plateau, India. Earth and Planetary Science Letters, v. 540, p. 8. doi:10.1016/j.epsl. 2020.116249

GSI, 2001, District Resources Map Series. Geological Survey of India Publications, Kolkata.

Kale, V.S., Kulkarni, H., and Peshwa, V.V., 1992, Discussion on: A geological map of the southern Deccan Traps, India and its structural implications. Journal Geological Society London, v. 149, pp. 473-478.

Kale, V.S., Dole, G., Shandilya, P. and Pande, K., 2019, Stratigraphy and correlations in Deccan Volcanic Province, India: Quo vadis? Bulletin Geological Society America, v. 132, pp. 588-607. doi:10.1130/B35018.1

Kale, V.S., 2020, Cretaceous volcanism in the Indian Plate: Rajmahal and Deccan Traps. In Eds. S.K. Tandon and N. Gupta: Geodynamics of the Indian Plate: An evolutionary perspective. Springer, pp. 233-298. doi:10.1007/978-3-030-15989-4_ 8

Kale, V.S., Bodas, M., Chatterjee, P. and Pande, K., 2020, Emplacement history and evolution of the Deccan Volcanic Province, India. Episodes, v. 43, pp. 278-299. doi:10.18814/epiiugs/2020/20015

Misra, K.S., 2002, Arterial system of lava tubes and channels within Deccan volcanics of western India. Journal Geological Society India, v. 59, pp. 115-124.

Misra, K.S., Bhutani, R., and Sonp, R., 2005, Discussion on "Seismology of Kutch and adjoining region with special reference to 26th January 2001 Earthquake in the vicinity of Bachua, Gujarat. Journal Geological Society of India, v. 66, pp. 379-388.

Nair, K.K.K., and Bhusari, B., 2001, Stratigraphy of Deccan traps: a review. In Roy, A., Bandopadhyay, B.K., Jain, S.C., Nair, K.K.K., Saha, A.K., Misri, J.L., Tiwari, M.P., Rao, K.V., Mohabey, D.M., and Sekhar, S. (Eds) Recent Advances in the field of Earth Sciences and their implications in National Development. Geological Survey of India, Special Publication, v. 64, pp. 477-941.

Òskarsson, B., and Riishuus, M. S., 2014, The mode of emplacement of Neogene flood basalts in eastern Iceland: facies architecture and structure of simple aphyric basalt groups. Journal Volcanology Geothermal Research, v. 289, pp. 170-192. doi:10.1016/j.jvolgeores.2014.11.009

Rossetti, L., Lima, E.F., Waichel, B.L., Hole, M.J., Simoes, M.S. and Scherer, C.M.S., 2018, Lithostratigraphy and volcanology of the Serra Geral Group, Parana Etendeka Igneous Province in southern Brazil: towards a formal stratigraphic framework. Journal Volcanology and Geothermal Research, p. 17, doi:10.1016/j.jvolcgeores.2017.05.008

Schoene, B., Eddy, M.P., Keller, C.B., and Samperton, K.M., 2020, An evaluation of Deccan Trap eruption rates using geochronological data. Geochronology - Discussions, doi:10.5194/gechron-2020-11

Self, S., Keszthelyi, L., and Thordarson, T., 1998, The importance of Pahoehoe. Annual Reviews Earth Planetary Science. v. 26, pp. 81-110.

Sen, B., Sabale, A.B., and Sukumaran, P.V., 2012, Lava channel of Khedrai dam, northeast of Nasik in Western Deccan Volcanic Province: detailed morphology and evidence of channel reactivation. Journal Geological Society India, v. 80, pp. 314-328.

Sen, B., 2017, Lava flow transition in pahoehoe dominated lava pile of Deccan Traps from Manmad - Chandwad area, Western Maharashtra. Journal Geological Society India, v. 89, pp. 281-190.

Shandilya, P., Chatterjee, P., Pattabhiram, K., Bodas, M., Pande, K., and Kale, V.S., 2020, Rajgad GPB: a megaporphyritic flow field, Western Deccan Volcanic Province, India. Journal Earth System Science, v. 129, p. 11, doi:10.1007/s12040-020-1375-3

Waichel, B.L., de Lima, E.F., Viana, A.R., Scherer, C.M., Bueno, G.V. and Dutra, G., 2012, Stratigraphy and volcanic facies architecture of the Torres Syncline, Southern Brazil, and its role in understanding the Parana - Etendeka Continental flood basalt province. Journal Volcanology and Geothermal Research, v. 215-216, pp. 74-82, doi:10.1016/ j.jvolcgeores.2011.12.004 


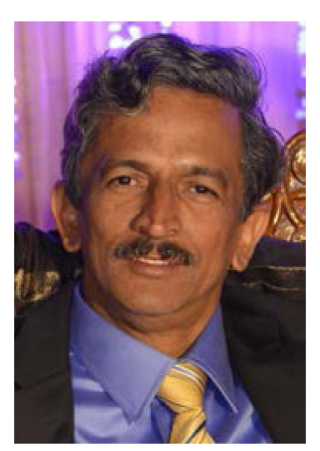

Vivek S. Kale obtained M.Sc. (Geology) degree from the University of Pune (since renamed as the Savitribai Phule Pune University) in 1981; and Ph.D. degree in 1985 under the guidance of Prof. V.V. Peshwa. He was on the faculty of the Geology Department of University of Pune between 1987 and 1999; before taking up an entrepreneurial role with the Kalyani Group of Industries and leading the Geospatial business. He also served as an Adjunct Professor of Earth Sciences (2015 - 2017) at the Indian Institute of Technology Bombay. He is one of the founders and currently Managing Trustee \& Treasurer of a not-for-profit organisation ACWADAM, Pune. His primary research interests are in the fields of (a) Proterozoic sedimentary basins and (b) the Deccan Traps and large igneous provinces.

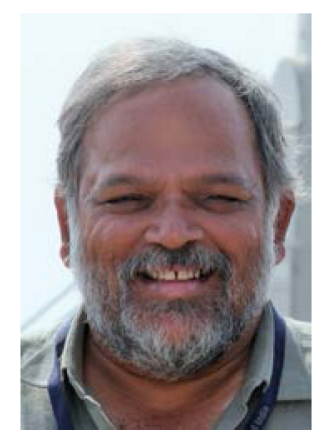

Makarand Bodas one of the pioneering contributors to the 'Chemostratigraphy' of the western Deccan Province, did his M.Sc from the Department of Geology, University of Pune in 1983 and obtained his $\mathrm{PhD}$ in Earth Sciences from the Indian Institute of Technology Bombay, Powai, Mumbai under the guidance of Prof. K.V. Subbarao, in 1991. He has been working for the Geological Survey of India for more than 30 years (from 1989) and is presently heading the Division of Volcanology. His work experience and research interests include the study of Deccan lavas, slope failures in the Deccan Volcanic Province and geology of Bundelkhand craton.

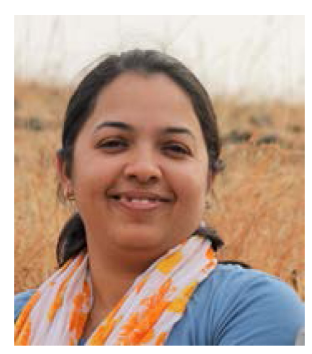

Poushali Chatterjee received her M. Sc. in geology from Ranchi University in 2008 and M. Tech. in Remote Sensing from Birla Institute of Technology (BIT), Mesra, Ranchi in 2011. She is currently a senior geologist with the Geological Survey of India in the Division of Volcanology, at Pune. She is engaged in study of the western Deccan lava pile with the objective of (a) developing 3D architecture of the Deccan lavas and (b) towards the elucidation of the stratotypes of formations the Deccan Volcanic Province.

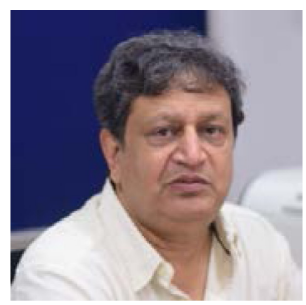

Kanchan Pande obtained M.Sc. (Geology) degree from the Kumaun University, Nainital in 1981, Ph.D. degree in 1990 under the guidance of Prof. K. Gopalan from Physical Research Laboratory (PRL), Ahmedabad (awarded by Gujarat University, Ahmedabad). He is currently a Professor at the department of Earth Sciences at IIT Bombay, Mumbai. His primary research interests are in the fields of (a) geochronology of Deccan Volcanic Province and (b) geo- and thermochronology of collisional tectonics. 